\title{
Response of Gas Exchange to Leaf Piercing Explained by Piecewise Linear Regression for Two Developmental Forms of Rape Plant (BRassica napus L. SSP. Oleifera MetzG)
}

\author{
Anna Wenda-PiesiK ${ }^{1 *}$, WŁodZIMierz KrZesiński ${ }^{2}$, AgnieszKa NowAK $^{1}$, \\ Maciej KaZEK ${ }^{1}$ AND Magdalena TOMASZEWSKA-SOWA ${ }^{3}$ \\ ${ }^{1}$ UTP University of Science and Technology, Department of Plant Growth Principles \\ and Experimental Methodology, Kordeckiego 20, 85-225 Bydgoszcz, Poland \\ ${ }^{2}$ University of Life Sciences in Poznań, Department of Vegetable Crops, \\ Dabrowskiego 159, 00-594 Poznań, Poland \\ ${ }^{3}$ UTP University of Science and Technology, Department of Plant Physiology \\ and Biotechnology, Bernardyńska 6, 85-029 Bydgoszcz, Poland
}

Received October 5, 2016; revision accepted December 22, 2016

\begin{abstract}
Oilseed rape (Brassica napus L. ssp. oleifera Metzg) was the subject of the study in two forms: winter $c v$. 'Muller' (at the rosette stage - the first internode $\mathrm{BBCH} 30$ - 31) and spring $c v$. 'Feliks' (at the yellow bud stage BBCH 59). The main gas-exchange parameters, net photosynthetic rate $\left(P_{\mathrm{N}}\right)$, transpiration rate $(E)$, stomatal conductance $\left(g_{\mathrm{s}}\right)$, and intercellular $\mathrm{CO}_{2}$ concentration $\left(C_{\mathrm{i}}\right)$ were measured on leaves prior to the piercing and immediately after the short-term piercing. The effect of mechanical wounding revealed different progress of the gas exchange process for the two forms. Piecewise linear regression with the breakpoint estimation showed that the plants at the same age but at a different vegetal stage, manage mechanical leaf-piercing differently. The differences concerned the stomatal conductance and transpiration changes since for rosette leaves the process consisted of five intervals with a uniform direction, while for stem leaves - of five intervals with a fluctuating direction. These parameters got stabilized within a similar time $(220 \mathrm{mins})$ for both forms. The process of net photosynthetic rate was altered by the plant stages. 'Muller' plants at the rosette stage demonstrated dependence of $P_{\mathrm{N}}$ on time in log-linear progression: $\mathrm{y}\left(P_{\mathrm{N}}\right)=8.01+2.73 \log _{10}\left(\mathrm{x} \mathrm{t}_{2}\right) ; 7<\mathrm{t}_{2}<220 ; R^{2}=0.96$. For stem leaves of 'Feliks' plants the process of transpiration, in terms of directions, was convergent with the process of photosynthesis. Those two processes were synchronized from $1^{\text {st }}$ to $114^{\text {th }}$ min of the test $(r=0.85 ; p<0.001)$ in plants at the rosette stage and from $26^{\text {th }}$ to $148^{\text {th }} \mathrm{min}$ in stem leaves $(r=0.95 ; p<0.001)$.
\end{abstract}

Keywords: leaf piercing response, oilseed rape, net photosynthetic rate, transpiration, stomatal conductance, concentration of intercellular $\mathrm{CO}_{2}$

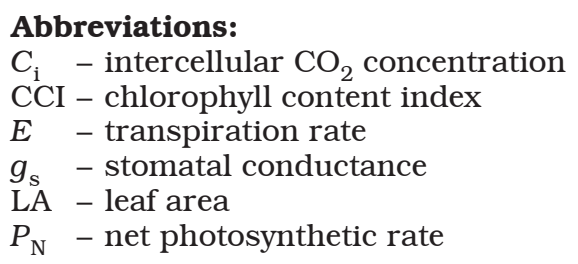

* Corresponding author, email: apiesik@utp.edu.pl 


\section{INTRODUCTION}

Biomass production mostly depends on the level of gas exchange between the plant and the environment. Stressful environments, including drought, salinity, and unfavorable temperatures, considerably hamper the process of photosynthesis in most plants by altering the ultrastructure of the organelles and concentration of various pigments and metabolites including enzymes involved in this process as well as stomatal regulation (Ashraf and Harris, 2013). Plant respiration can be disturbed by biotic and abiotic stressors (Roitsch, 1999). The appearance of the stress factor caused by, e.g., hailstorm (Muro et al., 1998; Tartachnyk and Blanke, 2002) or an invasion of plant-eating pests (Hawkins et al., 1987; Holman and Oosterhuis, 1999; Gomez et al., 2004) results in stomata closing, decreasing the intensity of photosynthesis, sometimes also increasing evaporation from leaves. Changes in the intensity of gas exchange occur immediately after the induction of stress reaction. The response to stress is detectable by the net photosynthetic rate as well as transpiration and mostly depends on the plant species and the size of the leaves left on the plant after defoliation as well as the presence or lack of the apical bud (Evans, 1991; Wang et al., 1997; Roitsch, 1999). Despite many various types of damage triggered by biotic factors (insects, viruses, fungi), for various host plants the mechanism of regulation is the same and it involves a decrease in the transcription of nuclear genes encoding the components of photosynthesis. Biotic leaf wounding causes almost complete inhibition of genes taking part in the process of photosynthesis. It is seen mostly for the genes connected with the synthesis of pigment and transport of electrons (Bilgin et al., 2010). After infection caused by pathogens or planteating insects the effort of the plant to decrease the amount of photosynthetic protein is necessary to support the defense induction. The leaf nitrogen is involved in; much of it is found in photosynthetic proteins, primarily in RuBisCO, and if limited, it can even lead to its use with RuBisCO (Paul and Foyer, 2001). The infestation of scale insects decreases the chlorophyll and carotenoid content as well as the value of three indicators of photosynthetic activity. The reactions depend on the specific properties of plants and abundance of insects feeding on them (Golan et al., 2015). The research into rape (Brassica napus var. oleifera) performed so far demonstrated that beetles feeding on pollen (Meligethes aeneus) decrease the activity of the photosynthetic apparatus or increase transpiration, through a clear decrease in photosynthesis in unprotected plants, high stomatal conductance and poor fixation of $\mathrm{CO}_{2}$. It is also known, as for that species, that the wounding compensation methods are high effective (Axelsen and Nielsen, 1990) and mostly result from its high genetic potential which facilitates the formation of a huge number of flower buds, namely about 4-5 thousand per plant. The rape plants artificially deprived of inflorescence on the main shoot demonstrate a photosynthesis compensation capacity, optimizing the parameters of gas exchange; they decrease stomatal conductance.

The effect of mechanical stress on leaves is ambiguous for photosynthesis when the following conditions are considered: the plant species and age, as well as the stress type and its duration (Biddington, 1984). It was confirmed by Blamowski et al. (2003) for two species representing the genus Brassica: radish and spring rape at the rosette stage, exposed to the same wounding, i.e., the oldest leaves removal or defoliation of the youngest ones with the apical stem. Stress affects the course of gas exchange, distribution of assimilates and plant growth. Moreover, each interference in the relationship and cooperation of the organs providing the source of recipients of organic compounds also disturbs the production and activity of growth regulators. The compounds can regulate the distribution of assimilates, growth and gas exchange by affecting the biosynthesis and activity of enzymes or the absorption of gases (Starck and Ubysz, 1976; Pinto, 1980).

The aim of the present research was to determine the effect of mechanical wounding caused by short-term piercing of leaves in rape in its two developmental forms: the winter form at the rosette stage - the first internode (BBCH 30-31) and spring rape plant at the yellow bud stage (BBCH 59), on the progress of variation in the processes of assimilation and transpiration as well as stomatal conductance and the content of intercellular $\mathrm{CO}_{2}$. We hypothesized that the leaves of the two cultivars (spring / winter form) belonged to $B$. napus sp., and because they came from plants at the same age but at different developmental stages (generative / vegetative), they represented various course of gas exchanges after a short leaf piercing.

\section{MATERIAL AND METHODS}

\section{PLANTS AND TREATMENT}

Oilseed rape (Brassica napus L. ssp. oleifera Metzg) was the subject of the study in two forms: winter $c v$. 'Muller' and spring $c v$. 'Felix'. Seeds obtained from a breeding company were germinated and grown in peat-filled pots $(15 \mathrm{~cm} \times 15 \mathrm{~cm}$ $\times 20 \mathrm{~cm}$ ) in a greenhouse at $9 / 3^{\circ} \mathrm{C}$ (day/night environment) during the spring of 2014. Watering was applied to maintain the moisture at $65 \%$ relative water content. After 21 days, these plants at 4-5 leaf stage $(\mathrm{BBCH} 14-15)$ were transferred 
to a chamber at $20 / 11^{\circ} \mathrm{C}$ (day/night) for 10 days, received $300 \mu \mathrm{mol} \mathrm{m}{ }^{-2} \mathrm{~s}^{-1}$ light for $14 \mathrm{~h}$ per day, the relative humidity was $50 \%$. Fertigation was applied according to the scheme with macronutrients ( $\mathrm{g} \mathrm{dm}^{-1}$ of nutrient solution): $2.0 \mathrm{Ca}\left(\mathrm{NO}_{3}\right)_{2} \cdot 4 \mathrm{H}_{2} \mathrm{O}$ (calcium nitrate tetrahydrate), $1.5 \mathrm{KNO}_{3}$ (potassium nitrate), $0.75\left(\mathrm{NH}_{4}\right)_{2} \mathrm{SO}_{4}$ (ammonium sulfate), $0.55 \mathrm{MgSO}_{4} \cdot 7 \mathrm{H}_{2} \mathrm{O}$ (magnesium sulfate heptahydrate), $0.35 \mathrm{KH}_{2} \mathrm{PO}_{4}$ (monopotassium phosphate) and for micronutrients $\left(\mathrm{g} \mathrm{dm}^{-1}\right.$ of nutrient solution): $0.33 \mathrm{Cu}$ IDHA, $2.0 \mathrm{Mn}$ IDHA, 0.57 $\mathrm{Zn}$ IDHA, $0.28 \mathrm{H}_{3} \mathrm{BO}_{3}, \mathrm{EC}=2.6$ and $\mathrm{pH}=5.6$. Application of nutrients was done twice a day with two emitters per pot dropping $100 \mathrm{ml}$ for $60 \mathrm{~s}$ (Ferdiga system). Rape plants in 60 pots (30 per each cultivar) were cultivated until they reached $\mathrm{BBCH}$ 30-31 (rosette - the first internode) - $c v$. 'Muller', and BBCH 59 (the first petals 'yellow bud') $-c v$. 'Feliks' plants. All plants were the same age, however, their varied development was due to the fact that $c v$. 'Muller', as a winter form, remained at the rosette (vegetative) stage, while $c v$. 'Feliks', as a spring form, started the generative stage. The treated, fully expanded third leaves were chosen with the uniform area and CCI (measured by the chlorophyll meter CCM-200 plus, Opti-Sciences, Inc., USA) - Table 1. Wounding by piercing of the total leaf area with the pins having a diameter of $1 \mathrm{~mm}$ and a density of 10 punches per $1 \mathrm{~cm}^{2}$ lasted 3 seconds.

\section{MEASUREMENTS}

The main gas-exchange parameters, net photosynthetic rate $\left(P_{\mathrm{N}}\right)$, transpiration rate $(E)$, stomatal conductance $\left(g_{\mathrm{s}}\right)$, and intercellular $\mathrm{CO}_{2}$ concentration $\left(C_{\mathrm{i}}\right)$ were measured prior to the piercing and immediately after the piercing at the center of the wounded area, the leaves were fitted into a $6.25 \mathrm{~cm}^{2}$ clamp-on Plant Leaf Chamber (PLC Broad with mixed Red/Blue LED array). Gas exchange measurements lasted 220 mins. This was performed using a portable open infrared $\mathrm{CO}_{2}$ gas analyzer (LC-Pro+, ADC BioScientific Ltd, Hoddesdon, UK) between 10:00-14:00 h. The system allowed for an automated microclimate control in the PLC. The conditions were stable in PLC and amounted to light $600 \mu \mathrm{mol} \mathrm{m} \mathrm{m}^{-2} \mathrm{~s}^{-1}, \mathrm{CO}_{2}$ concentration $360 \pm 5 \mathrm{ppm}$; temperature $22 \pm 1^{\circ} \mathrm{C}$, water vapor pressure $10 \pm 1$ mbar (relative humidity approx. 40\%). The rate of air flow through the LCpro+ chamber was approximately $200 \mathrm{ml} \cdot \mathrm{min}^{-1}$. These conditions provided the strongest response of plants to leaf piercing. In the growth chamber where the gas-exchange parameters were measured oxygen concentration was ambient (21\%).

\section{DATA ANALYSIS}

The analysis of piecewise linear regression with the breakpoint estimation was calculated to explain the time-relation changes of the parameters $g_{\mathrm{s}}, C_{\mathrm{i}}, P_{\mathrm{N}}$, and $E$. The time intervals were estimated by nonlinear methods according to Quasi-Newton and the lost function based on the least squares were proceeded (Haelterman et al., 2009). The relationships between the parameters were computed using the simple coefficient of correlation ( $r$ by Pearson). The results were processed using STATISTICA data analysis software system version 12.0 (StatSoft; Tulsa, Oklahoma, USA).

\section{RESULTS}

The characteristics of leaves are presented in Table 1. Both cultivars represented uniform LA $\left(F_{(1 ; 58)}=2.59, p=0.12\right)$, and the CCI was also statistically insignificant $\left(F_{(1 ; 58)}=3.44, p=0.07\right)$. The response to leaf piercing with pins was noticeable in both cultivars, however, its pattern varied in terms of the intensity of gas exchange parameters in time and in relationships between them.

\section{STOMATAL CONDUCTANCE}

AND INTERCELLULAR CARBON DIOXIDE CONCENTRATION AS RESPONSE TO LEAF PIERCING

Stomatal conductance before piercing amounted to $0.280 \mathrm{~mol} \mathrm{~m}^{-2} \mathrm{~s}^{-1}$ in 'Muller' winter rape plans and $0.390 \mathrm{~mol} \mathrm{~m}^{-2} \mathrm{~s}^{-1}$ in 'Felix' spring rape (Table 2). Upon leaf piercing, $g_{\mathrm{s} 1}$ decreased in 'Muller' by $0.01 \mathrm{~mol} \mathrm{~m}^{-2} \mathrm{~s}^{-1}$ within $1 \mathrm{~min}$, i.e., by $26 \%$ over 5.7 mins and in 'Feliks' it decreased by $0.006 \mathrm{~mol} \mathrm{~m}^{-2} \mathrm{~s}^{-1}$, i.e., by $7 \%$ over $5.9 \mathrm{mins}$ (Table 2). After the first interval $g_{\mathrm{s} 2}$ increased

TABLE 1. The characteristics of leaf of rape cultivars.

\begin{tabular}{crcccc}
\hline \hline \multirow{2}{*}{ Characteristic } & \multicolumn{3}{c}{ Cultivar/stage } & & \multirow{2}{*}{$F_{(1 ; 58)}$} \\
\cline { 2 - 4 } & $\begin{array}{c}\text { 'Muller' } \\
\text { BBCH 30-31 }\end{array}$ & $\begin{array}{c}\text { 'Feliks' } \\
\text { BBCH 59 }\end{array}$ & $p$ \\
\hline LA (c = 0.8) & $49.6 \pm 2.47$ & $44.2 \pm 2.30$ & 2.59 & 0.12 \\
\hline CCI & $21.13 \pm 1.36$ & $17.65 \pm 1.29$ & 3.44 & 0.07 \\
\hline
\end{tabular}


TABLE 2. Progress of stomatal conductance $\left[g_{\mathrm{s}}\right.$ ] changes after leaf piercing of two rape cultivars according to the piecewise linear regressions of the time and with confident limits (CL).

\begin{tabular}{|c|c|c|c|c|}
\hline Break point of time [min] & $95 \%$ CL of time & $g_{\mathrm{s}}\left[\mathrm{mol} \mathrm{\textrm {m } ^ { - 2 } \mathrm { s } ^ { - 1 } ]}\right.$ & $95 \% \mathrm{CL}$ of $g_{\mathrm{s}}$ & Relative stepwise change [\%] \\
\hline \multicolumn{5}{|c|}{$c v$ ‘Muller’ BBCH 30-31 } \\
\hline Starting $=0.0$ & - & 0.280 & - & 100 \\
\hline 5.7 & $5.5-5.9$ & 0.207 & $0.190-0.220$ & -26 \\
\hline 27.4 & $25.3-29.5$ & 0.242 & $0.238-0.246$ & +17 \\
\hline 58.5 & $54.7-62.4$ & 0.246 & $0.243-0.250$ & +1.7 \\
\hline 116.0 & $110-122$ & 0.294 & $0.289-0.300$ & +20 \\
\hline Ending $=220$ & - & 0.354 & - & +20 \\
\hline \multicolumn{5}{|c|}{$c v$ 'Feliks' BBCH 59} \\
\hline Starting $=0.0$ & - & 0.390 & - & 100 \\
\hline 5.9 & $5.0-6.8$ & 0.361 & $0.359-0.363$ & -7 \\
\hline 23.6 & $20.9-26.5$ & 0.384 & $0.376-0.391$ & +6 \\
\hline 63.4 & $60.4-66.4$ & 0.265 & $0.261-0.269$ & -29 \\
\hline 155.0 & $149-161$ & 0.408 & $0.407-0.409$ & +48 \\
\hline Ending $=220$ & - & 0.421 & - & +4 \\
\hline
\end{tabular}

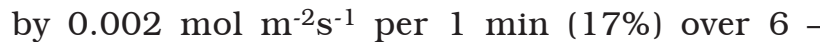
27.4 mins in 'Muller' and by $0.0013 \mathrm{~mol} \mathrm{~m}^{-2} \mathrm{~s}^{-1}(6 \%)$ over 6 - 23.6 mins in 'Feliks' (Figs. 1a, 1b). Over the next interval there was seen a diametrically opposite reaction of $g_{\mathrm{s}}$ between winter and spring plants; 'Muller' was going through a 30 mins period of uniform level $g_{\mathrm{s} 3}$ of $0.246 \mathrm{~mol} \mathrm{~m}^{-2} \mathrm{~s}^{-1}$, whereas in 'Feliks' $g_{\mathrm{s} 3}$ was decreasing for $40 \mathrm{mins}$, every min- ute by $0.0028 \mathrm{~mol} \mathrm{~m}^{-2} \mathrm{~s}^{-1}$, i.e., by $29 \%$, to the level of $0.265 \mathrm{~mol} \mathrm{~m}^{-2} \mathrm{~s}^{-1}$ (Table 2). Only about an hour after piercing, the plants of both rape plant forms started the period of $g_{\mathrm{s} 4}$ stabilization (Figs. 1a, 1b). In the 'Muller' plants, between $59^{\text {th }}$ and $116^{\text {th }} \mathrm{min}$, $g_{\mathrm{s} 4}$ increased by $0.001 \mathrm{~mol} \mathrm{~m}^{-2} \mathrm{~s}^{-1}$, i.e., by $20 \%$, and during successive $100 \mathrm{mins}\left(g_{\mathrm{s} 5}\right)$ also by $20 \%$, at the rate of $0.0004 \mathrm{~mol} \mathrm{~m}^{-2} \mathrm{~s}^{-1}$. In the 'Feliks' plants,

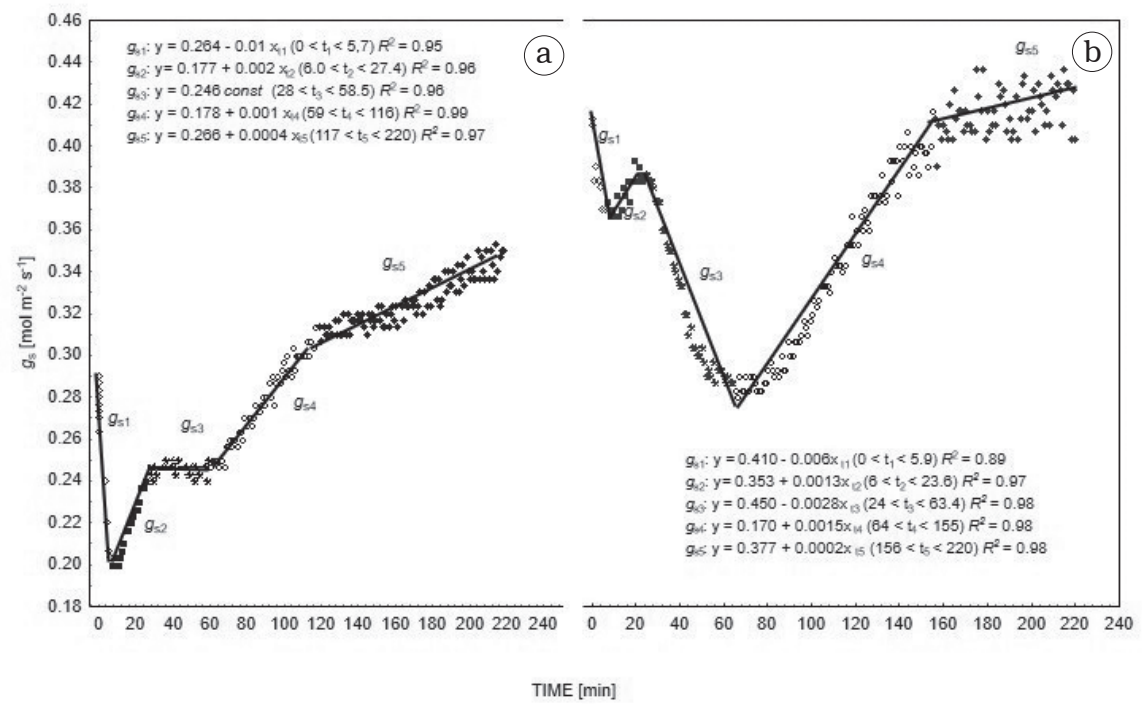

Fig. 1. Piecewise linear regressions for stomatal conductance after leaf piercing of rape plant. The confident limits $(95 \% \mathrm{CL})$ of the linear parameters, the duration of each interval (t) and coefficients of determination $\left(\mathrm{R}^{2}\right)$; (a) $c v$. 'Muller', (b) $c v$. 'Felix'. 
between $63^{\text {rd }}$ and $159^{\text {th }}$ min, $g_{\mathrm{s} 4}$ increased by $48 \%$ at the rate of $0.0015 \mathrm{~mol} \mathrm{~m}^{-2} \mathrm{~s}^{-1}$ per $1 \mathrm{~min}$, and for successive 65 mins $\left(g_{\mathrm{s} 5}\right)-$ by $4 \%$ at the rate of $0.0002 \mathrm{~mol} \mathrm{~m}^{-2} \mathrm{~s}^{-1}$ per $1 \mathrm{~min}$ (Table 2, Figs. 1a, 1b).

Prior to the piercing, the concentrations of intercellular $\mathrm{CO}_{2}\left(C_{\mathrm{i}}\right)$ were 211 and $214 \mu \mathrm{mol} \mathrm{mol}^{-1}$ for 'Muller' and 'Feliks', respectively (Table 4). Two minutes after piercing $C_{\mathrm{i} 1}$ increased by $22 \mu \mathrm{mol} \mathrm{mol}{ }^{-1}$ (11\%) in 'Feliks' and by $47 \mu \mathrm{mol} \mathrm{mol}^{-1}$ $(22 \%)$ in 'Muller' over 3 mins (Table 4$)$. An hour after the piercing, $C_{\mathrm{i}}$ displayed a similar tendency to increase together with the $g_{\mathrm{s}}$ increase in both cultivars. After the first interval of growth there followed two periods of decrease in $C_{\mathrm{i} 2}$ and $C_{\mathrm{i} 3} ; C_{\mathrm{i} 2}$ at a higher rate $\left(-1.77\right.$ and $-1.40 \mathrm{mmol} \mathrm{mol}^{-1}$ for 'Muller' and 'Feliks', respectively) and $C_{\mathrm{i} 3}$ - at a slower rate (-0.42 and $-0.18 \mu \mathrm{mol} \mathrm{mol}^{-1}$ for 'Muller' and 'Feliks', respectively). Such response lasted up to 46-64 mins after piercing, which was followed by the stage of $C_{\mathrm{i} 4}$ growth in both cultivars at the same rate (by $0.11 \mathrm{umol} \mathrm{mol}^{-1}$ every minute) taking from $46^{\text {th }}$ to $114^{\text {th }} \mathrm{min}$ in 'Muller' and from $63.5^{\text {th }}$ to $146^{\text {th }} \mathrm{min}$ in 'Feliks', and then the $C_{\mathrm{i} 5}$ period of stabilization (by $0.02 \mu \mathrm{mol} \mathrm{mol}{ }^{-1}$ in 'Feliks' and $0.05 \mu \mathrm{mol} \mathrm{mol}{ }^{-1}$ in 'Muller', every minute) - from $146^{\text {th }}$ to $220^{\text {th }}$ min and from $114^{\text {th }}$ to $220^{\text {th }}$ min of the test, respectively (Table 4, Figs. 2a, 2b).

Changes in $g_{\mathrm{s}}$ in 5 time sequences can be interpreted by the relationships between $C_{\mathrm{i}}$ and transpiration $(E)$, and net photosynthetic rate $\left(P_{N}\right)$, calculated as $r$-Pearson correlation coefficient and $b$ coefficient of regression (Table 3). Provided that the power and direction of the correlations between $g_{\mathrm{s}} v s . E$ and
$P_{\mathrm{N}}$ were similar for both rape cultivars after piercing stress in 5 time intervals and throughout the test, the relationship between $g_{\mathrm{s}}$ and $C_{\mathrm{i}}$ in the case of 'Muller' was different from that in 'Feliks'. In 'Feliks' it was a strong positive correlation between $C_{i}$ with $g_{\mathrm{s}}(r=0.86)$, while in 'Muller' - negative correlation with $r=-0.81$, which means that the leaves at the rosette stage retained $\mathrm{CO}_{2}$ during the decrease in $g_{\mathrm{s} 1,2}$ over $1^{\text {st }}-23^{\text {rd }}$ min, while the leaves at the flowering stage were losing intercellular $\mathrm{CO}_{2}$ with a decrease in $g_{\mathrm{s} 1.3}$ (from $1^{\text {st }}$ to $6^{\text {th }}$ min and from $24^{\text {th }}$ to $63^{\text {rd }}$ min) (Table 3, Figs. 2a, 2b). That proves the different initial response to the piercing. An hour after piercing the tendency in both cultivars got leveled off and resulted in an increase in $C_{\mathrm{i} 4}$ by 10.2 ('Muller') and 7.78 ('Feliks') $\mathrm{mol} \mathrm{m}{ }^{-2} \mathrm{~s}^{-1}$ with an increase in $g_{\mathrm{s} 4}$ by $0.1 \mathrm{~mol}$. After $2.5 \mathrm{~h}$, however, the tendency was maintained only in 'Feliks'. In that time segment the reactions between $g_{\mathrm{s}} v s . P_{\mathrm{N}}$ and $E$ got much weaker and between $7^{\text {th }}$ and $155^{\text {th }}$ min they showed very strong positive correlations, especially in 'Feliks' (Table 3).

\section{TRANSPIRATION AND NET PHOTOSYNTHETIC RATE RESPONSE TO LEAF PIERCING}

At the first stage after piercing (up to $7^{\text {th }} \min$ ) the leaves in 'Muller' reacted with a strong decrease in $P_{\mathrm{N} 1}(-35 \%)$ and $E_{1}(-22 \%)$ - (Tables 5, 6), which was, at the same time, correlated with an increase in $C_{\mathrm{i} 1}$ (Table 7). Then $P_{\mathrm{N} 2}$ was increasing in that cultivar in $\log$-linear progression as a time function, giving two segments of the rate; up to $47^{\text {th }}$ min by $0.055 \mu \mathrm{mol} \mathrm{m}{ }^{-2} \mathrm{~s}^{-1}$ and from $48^{\text {th }}$ to $220^{\text {th }}$

TABLE 3. Pearson's coefficients of correlation $(r)$ and slopes $(b)$ between $g_{\mathrm{s}} v s . C_{\mathrm{i}}, E$ and $P_{\mathrm{N}}$ parameters in time intervals for $c v$. 'Muller' and $c v$. 'Feliks' rape plants after leaf piercing.

\begin{tabular}{|c|c|c|c|c|c|c|c|}
\hline \multirow{2}{*}{ Interval [min] } & \multirow{2}{*}{ Coefficient } & \multicolumn{2}{|c|}{$C_{\mathrm{i}}$} & \multicolumn{2}{|c|}{$\boldsymbol{E}$} & \multicolumn{2}{|c|}{$P_{\mathrm{N}}$} \\
\hline & & 'Muller' & 'Feliks' & 'Muller' & 'Feliks' & 'Muller' & 'Feliks' \\
\hline \multirow{2}{*}{$1-6$} & $r$ & $-0.81^{*}$ & $0.86^{*}$ & $0.99^{* * *}$ & $0.98^{* * *}$ & $0.91^{* *}$ & $-0.28^{\mathrm{ns}}$ \\
\hline & $b$ & -49.6 & 2.27 & 0.90 & 0.77 & 0.85 & - \\
\hline \multirow{2}{*}{$7-23$} & $r$ & $-0.90^{* * *}$ & $-0.21^{\mathrm{ns}}$ & $0.99^{* * *}$ & $0.90^{* * *}$ & $0.97^{* * *}$ & $0.85^{* * *}$ \\
\hline & $b$ & -20.0 & - & 0.64 & 0.44 & 0.49 & 0.35 \\
\hline \multirow{2}{*}{$24-63$} & $r$ & $-0.23^{\mathrm{ns}}$ & $0.90^{* * *}$ & $0.55^{* * *}$ & $0.99^{* * *}$ & $0.48^{* *}$ & $0.96^{* * *}$ \\
\hline & $b$ & - & 7.57 & 0.48 & 0.47 & 0.56 & 1.74 \\
\hline \multirow{2}{*}{$64-155$} & $r$ & $0.82^{* * *}$ & $0.91^{* * *}$ & $0.96^{* * *}$ & $0.99^{* * *}$ & $0.83^{* * *}$ & $0.96^{* * *}$ \\
\hline & $b$ & 10.2 & 7.78 & 0.45 & 0.33 & 0.17 & 1.85 \\
\hline \multirow{2}{*}{$156-220$} & $r$ & $0.21^{\mathrm{ns}}$ & $0.80^{* * *}$ & $0.24^{\mathrm{ns}}$ & $0.32^{* *}$ & $0.37^{* *}$ & $0.10^{\mathrm{ns}}$ \\
\hline & $b$ & - & 12.9 & - & 0.15 & 0.13 & - \\
\hline \multirow{2}{*}{$1-220$} & $r$ & $0.20^{*}$ & $0.90^{* * *}$ & $0.95^{* * *}$ & $0.74^{* * *}$ & $0.86^{* * *}$ & $0.95^{* * *}$ \\
\hline & $b$ & 2.50 & 7.87 & 0.49 & 0.23 & 0.26 & 1.67 \\
\hline
\end{tabular}

$r$ - correlation coefficient by Pearson, $b$ - linear coefficient of regression, ${ }^{*}$ significance at $p=0.05,{ }^{* *} p=0.01,{ }^{* * *} p=0.001$, ns - not significant 
TABLE 4. Progress of intercellular $\mathrm{CO}_{2}$ concentration $\left[C_{i}\right]$ changes after leaf piercing of two rape cultivars according to the piecewise linear regressions of the time and with confident limits (CL).

\begin{tabular}{|c|c|c|c|c|}
\hline Break point of time [min] & 95\% CL of time & $C_{i}\left[\mu \mathrm{mol} \mathrm{mol}^{-1}\right]$ & $95 \% \mathrm{CL}$ of $C_{i}$ & $\begin{array}{c}\text { Relative stepwise } \\
\text { change [\%] }\end{array}$ \\
\hline \multicolumn{5}{|c|}{$c v$. 'Muller' BBCH 30-31 } \\
\hline Starting $=0.0$ & - & 211 & $194-229$ & 100 \\
\hline 3.0 & $0-3$ & 258 & $255-262$ & +22 \\
\hline 10.7 & $9-12$ & 239 & $237-242$ & -7 \\
\hline 46.3 & $44-49$ & 226 & $224-227$ & -5 \\
\hline 114 & $98-131$ & 233 & $231-234$ & +3 \\
\hline Ending $=220$ & - & 238 & - & +2 \\
\hline \multicolumn{5}{|c|}{ cv. 'Feliks' BBCH 59} \\
\hline Starting $=0.0$ & - & 214 & $213-215$ & 100 \\
\hline 2.0 & $0-2$ & 238 & $236-241$ & +11 \\
\hline 8.8 & $8-9.6$ & 226 & $225-227$ & -5 \\
\hline 63.5 & $58.3-8.6$ & 217 & $216-218$ & -4 \\
\hline 146 & $137-155$ & 226 & $225-227$ & +4 \\
\hline Ending $=220$ & - & 229 & - & +1.1 \\
\hline
\end{tabular}

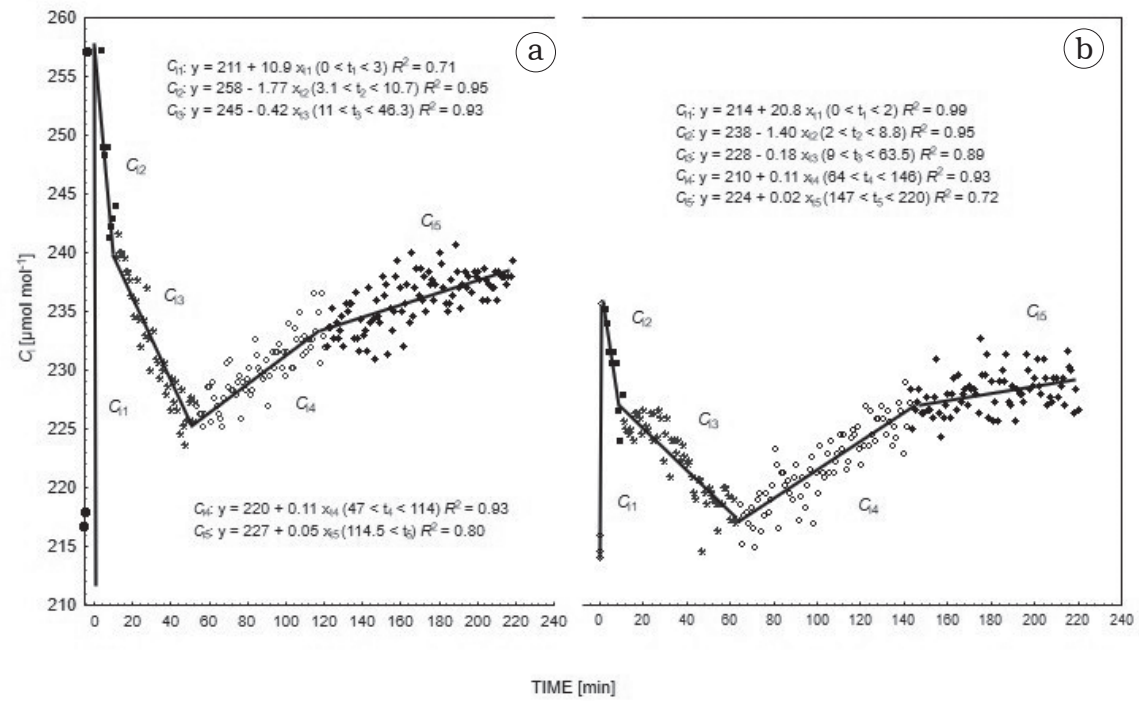

Fig. 2. Piecewise linear regressions for concentration of intercellular $\mathrm{CO}_{2}$ after leaf piercing of rape plant. The confident limits $(95 \% \mathrm{CL})$ of the linear parameters, the duration of each interval $(\mathrm{t})$ and coefficients of determination $\left(\mathrm{R}^{2}\right)$; $(\mathbf{a}) c v$. 'Muller', (b) $c v$. 'Felix'.

min by $0.006 \mu \mathrm{mol} \mathrm{m} \mathrm{m}^{-2} \mathrm{~s}^{-1}$ (Fig. 3a). The increase of $P_{\mathrm{N} 2}$ was accompanied by an increase in $C_{\mathrm{i} 4}$ only between $60^{\text {th }}$ and $114^{\text {th }} \mathrm{min}$; however, throughout the test the tendency was slightly negatively correlated ( $r=-0.25$ ) (Table 7$)$. In 'Muller' there was found a very strong association of the increasing $E_{1-4}$ to increasing $P_{\mathrm{N} 2}$ up to $114^{\text {th }}$ min of the test, after which both processes no longer showed a lin- ear dependence. The very pattern of $E_{3}$ in 'Muller' was convergent with the $g_{\mathrm{s} 3}$ pattern, with the phase of 'dormancy' between $28^{\text {th }}$ and $59^{\text {th }}$ min, and two growth intervals, namely a rapid increase between $7^{\text {th }}$ and $28^{\text {th }}$ min by $0.017 \mathrm{mmol} \mathrm{m}^{-2} \mathrm{~s}^{-1}$ per min and $0.005 \mathrm{mmol} \mathrm{m}^{-2} \mathrm{~s}^{-1}$ slower over $60^{\text {th }}-114^{\text {th }}$ min after piercing (Fig. 4a, Table 6). The $P_{\mathrm{N}}$ and $E$ changes in 'Feliks' showed a completely differ- 
TABLE 5. Progress of net photosynthetic rate $\left[P_{N}\right]$ changes after leaf piercing of two rape cultivars according to the piecewise linear regressions of the time and with confident limits (CL).

\begin{tabular}{|c|c|c|c|}
\hline Break point of time [min] & $P_{\mathrm{N}}\left[\mu \mathrm{mol} \mathrm{\textrm {m } ^ { - 2 } \mathrm { s } ^ { - 1 } ]}\right.$ & $95 \%$ CL of $P_{\mathrm{N}}$ & Relative stepwise change [\%] \\
\hline \multicolumn{4}{|c|}{ cv. 'Muller' BBCH 30-31 } \\
\hline Starting $=0.0$ & 15.7 & - & 100 \\
\hline 7.0 & 10.2 & $9.5-10.9$ & -35 \\
\hline 47.0 & 12.7 & $12.1-13.3$ & +25 \\
\hline Ending $=220$ & 14.4 & $13.9-14.9$ & +13 \\
\hline \multicolumn{4}{|c|}{ cv. 'Feliks' BBCH 59} \\
\hline Starting $=0.0$ & 19.27 & $19.2-19.3$ & 100 \\
\hline 1.0 & 16.07 & $15.9-16.3$ & -17 \\
\hline 25.5 & 17.35 & $17.1-17.6$ & +8 \\
\hline 74.0 & 14.94 & $14.7-15.2$ & -14 \\
\hline 148.0 & 17.83 & $17.6-18.1$ & +19 \\
\hline Ending $=220$ & 17.88 & - & +0.3 \\
\hline
\end{tabular}

TABLE 6. Progress of transpiration rate $[E]$ changes after leaf piercing of two rape cultivars according to the piecewise linear regressions of the time and with confident limits (CL).

\begin{tabular}{|c|c|c|c|c|}
\hline Break point of time [min] & $95 \% \mathrm{CL}$ of time & 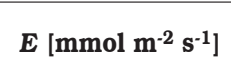 & $95 \%$ CL of $E$ & $\begin{array}{c}\text { Relative stepwise change } \\
{[\%]}\end{array}$ \\
\hline \multicolumn{5}{|c|}{ cv. 'Muller' BBCH 30-31 } \\
\hline Starting $=0.0$ & - & 3.58 & - & 100 \\
\hline 6.6 & $6.2-6.9$ & 2.79 & $2.75-2.84$ & -22 \\
\hline 27.5 & $27.3-28.1$ & 3.15 & $3.14-3.16$ & +13 \\
\hline 59.5 & $55.4-63.5$ & 3.17 & $3.17-3.17$ & +0.6 \\
\hline 114.0 & $110-118$ & 3.48 & $3.46-3.50$ & +10 \\
\hline Ending $=220$ & - & 3.56 & - & +2 \\
\hline \multicolumn{5}{|c|}{ cv. 'Feliks' BBCH 59} \\
\hline Starting $=0.0$ & - & 4.05 & - & 100 \\
\hline 9.0 & $6.5-10.6$ & 3.82 & $3.79-3.88$ & -5.2 \\
\hline 19.3 & $16.5-22.0$ & 3.93 & $3.91-3.95$ & +2.9 \\
\hline 65.5 & $47.5-83.4$ & 3.34 & $3.11-3.57$ & -15 \\
\hline 139.4 & $134-144$ & 3.72 & $3.68-3.74$ & +11 \\
\hline Ending $=220$ & - & 3.63 & - & -2.4 \\
\hline
\end{tabular}

ent pattern after piercing. In the first minute after piercing there was recorded a decrease in $P_{\mathrm{N} 1}$ from 19.27 to $16.07 \mu \mathrm{mol} \mathrm{m} \mathrm{m}^{-2} \mathrm{~s}^{-1}$, i.e., by $17 \%$ (Table 5) and within 9 mins the decrease in the $E_{1}$ from 4.05 to $3.82 \mathrm{mmol} \mathrm{m}^{-2} \mathrm{~s}^{-1}$, i.e., by $5.2 \%$ (Table 6 ). Then, both processes started to increase; $P_{\mathrm{N} 2}$ for 24 mins at the rate of $0.05 \mu \mathrm{mol} \mathrm{m} \mathrm{m}^{-2} \mathrm{~s}^{-1}$ and $E_{2}$ for $10 \mathrm{mins}$ at the rate of $0.009 \mathrm{mmol} \mathrm{m}^{-2} \mathrm{~s}^{-1}$ (Figs. 3b, 4b).
At that time there was reported a significant negative dependence between a decrease in $P_{\mathrm{N} 1}$ and an increase in $C_{i 1}$ (Table 7 ). At the third stage, which took place from $26^{\text {th }}$ to $74^{\text {th }}$ min there occurred a decrease in $P_{\mathrm{N} 3}$ by $0.04 \mu \mathrm{mol} \mathrm{m} \mathrm{m}^{-2} \mathrm{~s}^{-1}$ and $E_{3}$ by $0.013 \mathrm{mmol} \mathrm{m} \mathrm{m}^{-2} \mathrm{~s}^{-1}$. Directional convergence of those two processes was confirmed by the coefficient of correlation $r=0.95$. At the same time the 
TABLE 7. Pearson's coefficients of correlation $(r)$ and slopes $(b)$ between $P_{\mathrm{N}} v s . C_{i}$ and $E$ parameters in time intervals for $c v$. 'Muller' and $c v$. 'Feliks' rape plants after leaf piercing.

\begin{tabular}{|c|c|c|c|c|c|c|}
\hline \multirow{2}{*}{ Coefficient } & \multicolumn{3}{|c|}{ 'Muller' } & \multicolumn{3}{|c|}{ 'Feliks' } \\
\hline & Interval [min] & $P_{\mathrm{N}}$ vs. $C_{i}$ & $P_{\mathrm{N}} v s . E$ & Interval [min] & $P_{\mathrm{N}}$ vs. $C_{i}$ & $P_{\mathrm{N}}$ vs. E \\
\hline$r$ & \multirow{2}{*}{$1-6$} & $-0.97 * * *$ & $0.93^{* * *}$ & \multirow{2}{*}{$1-25$} & $-0.84^{* * *}$ & $-0.1 \mathrm{~ns}$ \\
\hline$b$ & & -0.15 & 9.52 & & -0.11 & - \\
\hline$r$ & \multirow{2}{*}{$7-27$} & $-0.96^{* * *}$ & $0.97 * * *$ & \multirow{2}{*}{$26-74$} & $0.76^{* *}$ & $0.95^{* *}$ \\
\hline$b$ & & -0.22 & 7.36 & & 0.16 & 3.65 \\
\hline$r$ & \multirow{2}{*}{$28-59$} & $-0.90 * * *$ & $0.50^{* *}$ & \multirow{2}{*}{$75-148$} & $0.75^{* *}$ & $0.95^{* *}$ \\
\hline$b$ & & -0.11 & 7.46 & & 0.19 & 5.36 \\
\hline$r$ & \multirow{2}{*}{$60-114$} & $0.46^{* * *}$ & $0.87^{* * *}$ & \multirow{2}{*}{$149-220$} & $-0.37 * *$ & $-0.19 \mathrm{~ns}$ \\
\hline$b$ & & 0.08 & 3.46 & & -0.05 & - \\
\hline$r$ & \multirow{2}{*}{$115-220$} & $-0.55^{* * *}$ & $0.00 \mathrm{~ns}$ & \multirow{2}{*}{$1-220$} & $0.73^{* * *}$ & $0.65^{* * *}$ \\
\hline$b$ & & -0.07 & - & & 0.15 & 3.64 \\
\hline$r$ & \multirow{2}{*}{$1-220$} & $-0.25^{* *}$ & $0.93^{* * *}$ & & & \\
\hline$b$ & & -0.06 & 5.39 & & & \\
\hline
\end{tabular}

$r$ - correlation coefficient by Pearson, $b$ - linear coefficient of regression, ${ }^{*}$ significance at $p=0.05,{ }^{* *} p=0.01,{ }^{* * *} p=0.001$, ns-not significant

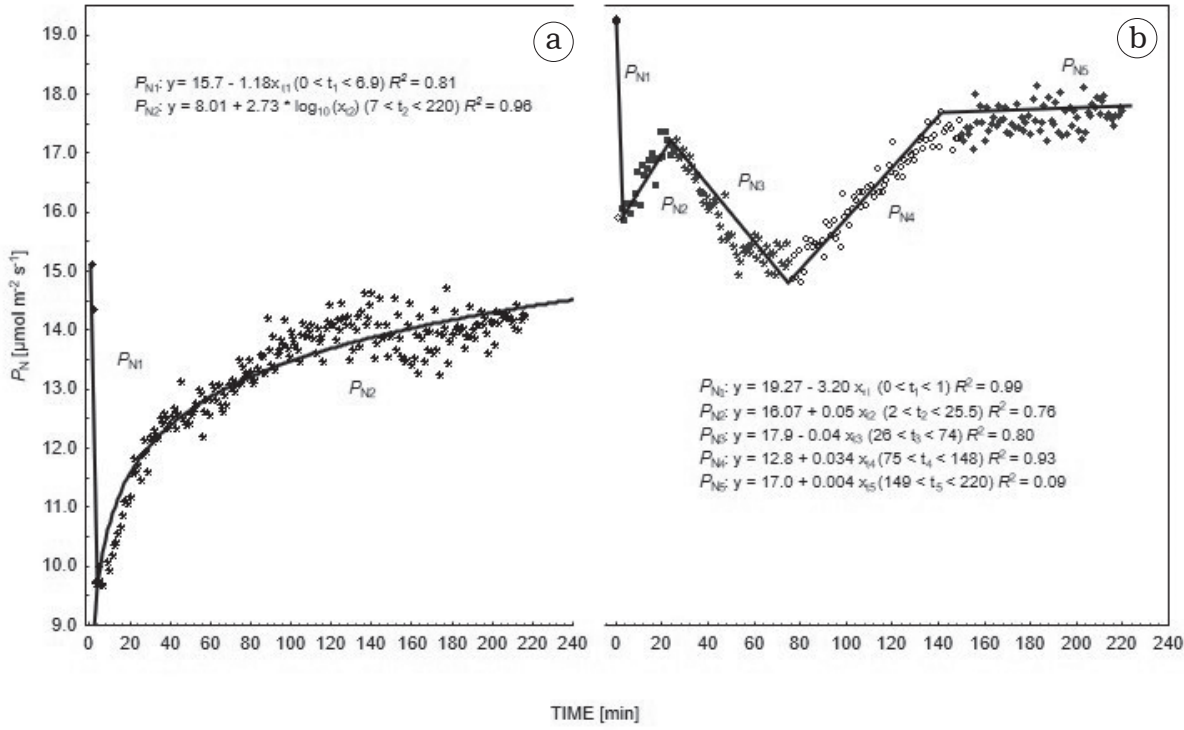

Fig. 3. Piecewise linear regressions and log-time regression for net photosynthetic rate after leaf piercing of rape plant, the duration of each interval (t) and coefficients of determination ( $\left.\mathrm{R}^{2}\right)$; (a) $c v$. 'Muller', (b) $c v$. 'Felix'.

dependence between $C_{\mathrm{i} 3}$ and $P_{\mathrm{N} 3}$ got reversed. At the successive stage there occurred rapid increasing in $P_{\mathrm{N} 4}$ (by $19 \%$ ) (Table 5 ) and $E_{4}$ (by $11 \%$ ) (Table 6 ), which lasted to $148^{\text {th }} \mathrm{min}$ and demonstrated strongly convergent processes. After that, to the end of the test, there was observed stabilization of both processes with non-significant correlation between them, an increase in $P_{\mathrm{N} 5}$ of $0.004 \mu \mathrm{mol} \mathrm{m} \mathrm{m}^{-2} \mathrm{~s}^{-1}$ and a slow decrease in $E_{5}$ by $0.0016 \mathrm{mmol} \mathrm{m}^{-2} \mathrm{~s}^{-1}$ (Figs. 3b, 4b). In stem leaves in 'Feliks' the pattern of $E$ was convergent in terms of the directions to the one observed for $P_{\mathrm{N}}$. Those two processes were synchronized from $1^{\text {st }}$ to $114^{\text {th }}$ min of the test in plants at the rosette stage and from $26^{\text {th }}$ to $148^{\text {th }}$ min of 

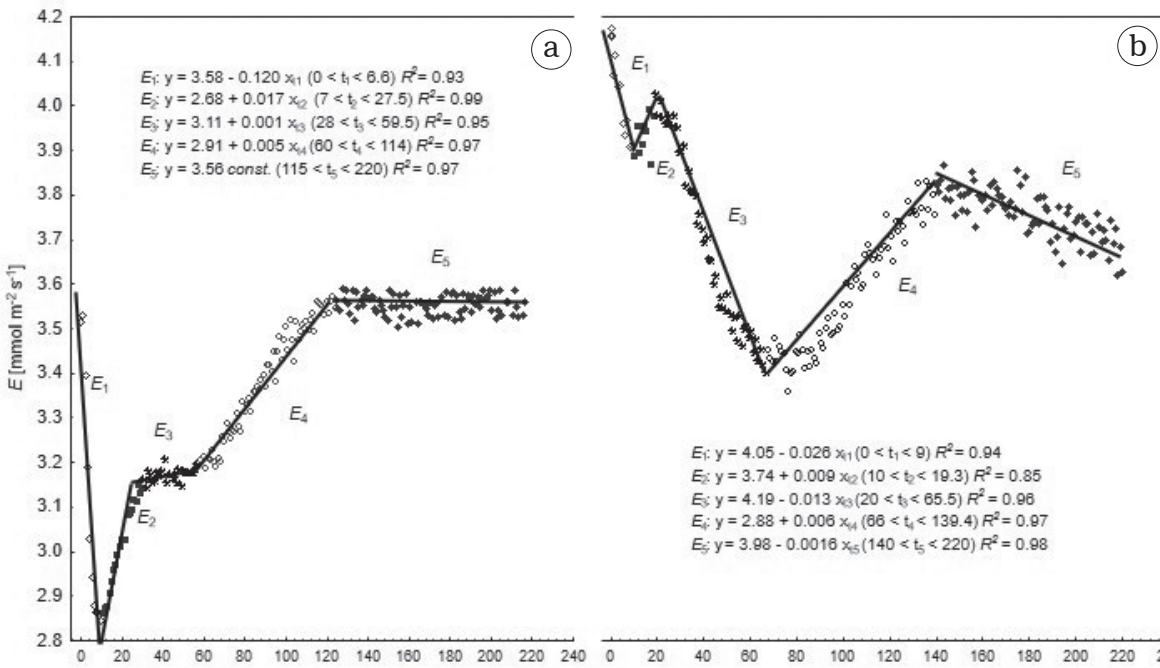

$E_{1:} \mathrm{y}=4.05-0.026 \times x_{1}\left(0<\mathrm{t}_{1}<9\right) R^{2}=0.94$ E: $y=3.74+0.009 \times 20\left(10<t_{2}<19.3\right) R^{2}=0.85$ $E_{3} \mathrm{y}=4.19-0.013 \times 3 \times(20<6<65.5) R^{2}=0.96$ $E_{i} y=2.88+0.006 x_{4}(66<t<139.4) R^{2}=0.97$ $E \cdot y=3.98-0.0016 \times x_{5}(140<t<220) R^{2}=0.98$

TMME [min]

Fig. 4. Piecewise linear regressions for transpiration after leaf piercing of rape plant. The confident limits (95\% CL) of the linear parameters, the duration of each interval (t) and coefficients of determination ( ${ }^{2}$ ); (a) $c v$. 'Muller', (b) $c v$. 'Felix'.

the test for stem leaves (Table 7). Besides, throughout the time interval ( $1^{\text {st }}-220^{\text {th }} \mathrm{min}$ ) for 'Muller' the positive correlation $(r)$ between $P_{\mathrm{N}}$ and $E$ was very high $0.93(p<0.001)$ and for 'Feliks' - it was high $r=0.65(p<0.001)$.

\section{DISCUSSION}

Gas exchange regulation is of great importance for water balance and the uptake of $\mathrm{CO}_{2}$. Controlling $g_{\mathrm{s}}$ is a complex process which depends on the water potential in leaves and on the intensity of transpiration as well as on such factors as the gradients of $\mathrm{CO}_{2}$ concentration or the quality and intensity of light (Mott and Parkhurst, 1991; Sperry and Pockman, 1993; Messinger et al., 2006; Shimazaki et al., 2007).

Our research demonstrated that the plants of the same species, but at two $\mathrm{BBCH}$ stages, display different $g_{\mathrm{s}}$ changes after leaf piercing. Blamowski et al. (2003) studied two species of the Brassica genus; radish and spring rape, both at the rosette stage, exposed to wounding: the oldest leaves removal or defoliation of the youngest ones with the apical stem. The oldest leaves removal resulted in the same reaction in both species; it increased the intensity of transpiration; however, it did not affect the intensity of assimilation. The defoliation of the youngest leaves with the apical meristem showed a completely different effect in radish and spring rape plants. In the case of radish, the authors do not relate any effect on the photosynthesis to the fact that at the rosette stage there occurs a very active acceptor of nutrient compounds (hypocotyl) which absorbs large amounts of carbon compounds supplied from leaves. This prevented the inhibition of photosynthesis, whereas in rape plants the defoliation of the youngest leaves with the apical meristem significantly decreased the intensity of assimilation, due to the accompanying increase of intercellular $\mathrm{CO}_{2}$ concentration and slight fluctuations of the value of $g_{\mathrm{s}}$, which pointed to non-stomatal limiting of photosynthesis. Koziołek et al. (2013) also described various stomatal conductance changes in leaves of shy plant (Mimosa pudica) due to abiotic factors, e.g., after thermal and light stimulation. The reaction after such stimulation on one part of the leaf showed a variable $g_{\mathrm{s}}$ pattern for the neighboring leaf part in the system of open and rolled pinnules after touching. For the open leaf at the first $g_{\mathrm{s}}$ stage it was a rapid growth about $40 \mathrm{~s}$ after thermal stimulation and taking about 1.7 mins, where $g_{\mathrm{s}}$ reached the maximum value of $0.180 \mathrm{~mol} \mathrm{~m}^{-2} \mathrm{~s}^{-1}$, after which it decreased to $0.050 \mathrm{~mol} \mathrm{~m}^{-2} \mathrm{~s}^{-1}$ and reached the period of stabilization after about 33 mins, at the level slightly lower than the initial state. This process is very similar to that in 'Feliks' spring rape plant analyzed here after leaf piercing (Fig. 1b). Meanwhile, $g_{\mathrm{s}}$ in closed leaflets of shy plant, due to thermal and light stress, changed similarly to the one described here for 'Muller' winter rape plants. At the initial value $g_{\mathrm{s}} 0.150 \mathrm{~mol} \mathrm{~m}^{-2} \mathrm{~s}^{-1}$ 8.3 min after induction there was a 3 fold decrease to $0.048 \mathrm{~mol} \mathrm{~m}^{-2} \mathrm{~s}^{-1}$, then a slow increase started and after about 28.3 mins $-g_{\mathrm{s}}$ stabilization which, 
finally, achieved the value higher than before the stress (Koziołek et al., 2013). The mechanical stress due to cutting of the main vein in sunflower (Heliathus annuus) leaf, disturbed the processes of $P_{\mathrm{N}}, E$ and stomatal conductance since it increased $g_{\mathrm{s}}$ by $0.22-0.23 \mathrm{~mol} \mathrm{~m}^{-2} \mathrm{~s}^{-1}$. The increase was compliant with the increase in $E$, which shows that the decrease in $P_{\mathrm{N}}$ observed was not an effect of limiting the release of $\mathrm{CO}_{2}$, which can occur upon decreased $g_{\mathrm{s}}$ (Hanson et al., 2013). A decrease in $P_{\mathrm{N}}$ and increase in $E$ were noted immediately after the cutting of the main vein. Photosynthesis reached the minimum value, on average, within $64 \mathrm{~s}$ after cutting-in, whereas the transpiration ratio assumed the highest value much later $(p=0.0006)$, on average within $143 \mathrm{~s}$ after cutting-in (Henson et al., 2013). In our research, in pierced 'Muller' leaves $E$ first decreased by $22 \%$ and after 7 mins it started increasing rapidly to $27^{\text {th }} \min (+13 \%)$, then it became slower for 30 mins $(+0.6 \%)$, and then increased by another $10 \%$ within 114 mins after piercing and it got stabilized to the initial value before the test. The plants of tomato Lycopersicon esculentum Mill. responded to chilling, as the stress factor, with stomatal conductance decreased by $32.2 \%$, as compared with the control plants (Artuso et al., 2000). In reference to the stressinducing factors of biotic origin, the reaction of $g_{\mathrm{s}}$ in leaves is differently described by researchers. As reported by Nabity et al. (2013) for wild tobacco (Nicotiana attenuata) plants damaged by tobacco hornworm (goliath worm) (Manduca sexta L.) and Aldea et al. (2005) for soybean (Glycine max L., cv. Pioneer 93B15) plants damaged by Japanese beetles (Popillia japonica) and corn caterpillars (Helicoverpa zea Bodie), the stress induced by plant-eating insects did not have a significant effect on $g_{\mathrm{s}}$ on wounded plants. Other biotic factors, e.g., viral infections, can cause changes in $g_{\mathrm{s}}$, as demonstrated for mustard plants (Brassica juncea var. tsatsai) infected with turnip virus (Guo et al., 2005). No such reactions to mechanically-induced stress in other plants have been recorded. Nabity et al. (2013) found that the wild-type plants Nicotiana attenuata demonstrated a slight increase in $C_{\mathrm{i}}$ (by $1 \%$ ), while the modified plants - a $3.8 \%$ decrease due to Manduca sexta L. insects feeding. Guo et al. (2005), on the other hand, report on $C_{\mathrm{i}}$ in leaves of the control plants and those infected with turnip mosaic virus in Brassica juncea var. tsatsai, being almost identical. Only Artuso et al. (2000) demonstrated that thermal stress (chilling) resulted in a decrease in the concentration of intercellular $\mathrm{CO}_{2}$ in Lycopersicon esculentum Mill. (by 6.4\%); however, the decrease was non-significant. According to Hinckley and Braatne (1994), stomatal conductance is inversely correlated with the concentration of carbon dioxide in leaves if tissues are adequately irri- gated. Nardini et al. (2003) show linear dependence between gas exchange and water vapor conductance and the parameters are closely correlated with each other $\left(r^{2}=0.987, p<0.01\right)$. We found strong positive correlation between $g_{\mathrm{s}}$ and $C_{\mathrm{i}}(r=0.86)$ for stem leaf wounded ('Feliks'), while in 'Muller' - they negatively correlated with $r=-0.81$, which means that the leaves at the rosette stage retained $\mathrm{CO}_{2}$ during the decrease in $g_{\mathrm{s}}$ over $1^{\text {st }}-23^{\text {rd }} \mathrm{min}$, while the leaves at the flowering stage were losing intercellular $\mathrm{CO}_{2}$ with a decrease in $g_{\mathrm{s}}$ (from $1^{\text {st }}$ to $6^{\text {th }} \mathrm{min}$ and from $24^{\text {th }}$ to $63^{\text {rd }} \mathrm{min}$ ). Photosynthesis and transpiration are, most frequently, correlated with each other due to the fact that stomata determine the conductance of water vapor and carbon dioxide (Farquhar and Sharkey, 1982). Mechanical leaf wounding in tomato resulted in an increase in the photosynthesis rate $1-5$ mins after wounding (Herde et al., 1999). In our research, after the period of a rapid decrease, increasing $P_{N}$ took place from $2^{\text {nd }}$ to $7^{\text {th }}$ min, earlier in rosette leaves and later in stem leaves. However, the latter did not reach the stabilization of $P_{\mathrm{N}}$ yet, showing successive decrease of $P_{\mathrm{N}}$ by $14 \%$ after 25 mins and only after 75 mins $P_{\mathrm{N}}$ started to get stabilized. Unlike 'Muller' plants at the rosette stage, there was demonstrated dependence of $P_{\mathrm{N}}$ on time in $\log$-linear progression: y $\left(P_{\mathrm{N}}\right)=8.01+2.73 \log _{10}\left(\mathrm{x} \mathrm{t}_{2}\right) ; 7<\mathrm{t}_{2}<220$; $R^{2}=0.96$. The research reported by Hanson et al. (2013) shows that the response to the stress of cutting-in the midvein in sunflower was a fast decrease in $P_{\mathrm{N}}$ by an average of $8.5 \pm 4.1 \mu \mathrm{mol} \mathrm{CO}_{2} \mathrm{~m}^{-2} \mathrm{~s}^{-1}$, i.e., by $40 \%$, as compared with the status before the stress. Here, that decrease amounted to $35 \%$ at the rosette stage and to $31 \%$ in stem leaves, however, in the latter the decrease occurred in two-stages; $17 \%$ in the range from piercing to $1^{\text {st }}$ min and $14 \%$ from $26^{\text {th }}$ to $74^{\text {th }}$ min. Midvein cutting-in in sunflower leaf also increased the process of $E$ by $1.3 \pm$ $1.0 \mathrm{mmol} \mathrm{H}_{2} \mathrm{O} \mathrm{m}^{-2} \mathrm{~s}^{-1}$ (Hanson et al., 2013). As reported by Artuso et al. (2000), processes $P_{\mathrm{N}}$ and $E$ in tomato demonstrated a considerable decrease due to chilling stress by $37.7 \%$ and $29.5 \%$, respectively, however, the authors do not describe how they were synchronized. Although genetic differences in photosynthetic capacity exist at intraspecific and interspecific levels, $P_{\mathrm{N}}$ is considered as one of the potential, physiological, selection criteria for stress tolerance (Ashraf, 2004). The reactions of plants to the effect of biotic stresses, mostly triggered by insects or viral pathogens, visible through changes in $P_{\mathrm{N}}$ and $E$ of leaves, were studied at many stages. Infecting mustard plants with turnip mosaic virus appeared an essential factor decreasing the $P_{\mathrm{N}}$ by $52 \%$, while for $E$ at the initial stage of infection it did not matter, after which there was observed an increase in $E$ and, at the final stage, a decrease, which was in no way related to the pattern of chang- 
es in $P_{\mathrm{N}}$ (Guo et al., 2005). Comparisons of the reaction of tobacco to two types of stress were investigated by Hlaváčková et al. (2002). The mechanical wounding of Nicotiana benthamiana leaf surface significantly decreased the process of

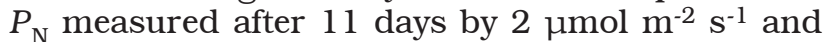
additional infection of those leaves with virus PPV (plum pox potyvirus) - by $4 \mu \mathrm{mol} \mathrm{m} \mathrm{m}^{-2} \mathrm{~s}^{-1}$, which, in relative values, accounted for $34 \%$ and $62 \%$, as compared with the control (unwounded) leaves. Thirty-nine days after inoculation/mechanical wounding, a decrease in $P_{\mathrm{N}}$ was, in both cases, similar and it accounted for $40 \%$. For that reason the cited authors' claim that $P_{\mathrm{N}}$ and $E$ are not synchronized after stress does not get confirmation; the authors state that at minimum $P_{\mathrm{N}}, E$ was maximum. In our research those two processes were synchronized from $1^{\text {st }}$ to $114^{\text {th }}$ min of the test in plants at the rosette stage and from $26^{\text {th }}$ to $148^{\text {th }}$ minute of the test in plants at the stem stage. Besides, throughout all time intervals $\left(1^{\text {st }}-220^{\text {th }}\right.$ $\min$ ) for 'Muller' the positive correlation $(r)$ between $P_{\mathrm{N}}$ and $E$ was very high $0.93(p<0.001)$ and for 'Feliks' - high $0.65(p<0.001)$.

We conclude that the only convergent process in both rape plant forms was observed for the concentration of intercellular $\mathrm{CO}_{2}$. Here, after a rapid increase in $C_{\mathrm{i}}$ (by $11-22 \%$ ) taking $2-3$ minutes after piercing, there occurred two stages of decrease and two stages of increase and in both leaf types the $C_{\mathrm{i}}$ level at the end of the test exceeded the initial level by an average of $15-27 \mu \mathrm{mol} \mathrm{mol}{ }^{-1}$.

\section{AUTHORS' CONTRIBUTIONS}

AW-P is the author of the concept, statistical analyses, wrote the manuscript, WK designed the research, collected data, wrote the manuscript, AN collected data, obtained funding, wrote the manuscript, MK collected data, MT-S prepared plants.

\section{ACKNOWLEDGEMENTS}

This research work was supported by Polish Ministry of Science and Education, Grant for young scientist No: BSM 54/2014.

\section{REFERENCES}

Aldea M, Hamilton JG, Resti JP, Zangelr AR, Berenbaur MR, and DELUCIA EH. 2005. Indirect effects of insect herbivory on leaf gas exchange in soybean. Plant, Cell and Environment 28: 402-411.

Artuso A, Guidi L, Soldatini GF, Pardossi A, and Tognoni F. 2000. The influence of chilling on photosynthesis and ac- tivities of some enzymes of sucrose metabolism in Lycopersicon esculentum Mill. Acta Physiologiae Plantarum 22: 95-101.

ASHRAF M. 2004. Some important physiological selection criteria for salt tolerance in plants. Flora 199: 361-376.

ASHRAF M, and HARRIS PJC. 2013. Photosynthesis under stressful environments: An overview. Photosynthetica 51: 163-190.

AXELSEN J, and Nielsen PS. 1990. Compensation in spring sown oilseed rape after attack by pollen beetles (Meligethes aeneus F.). Tidsskrift for Planteavl 94 (2): 195-199.

BIDDINGTON NL. 1984. The effect of mechanically-induced stress in plant - a review. Plant Growth Regulation 4: 108-122.

Bilgin DD, Zavala JA, Zhu J, Clough SJ, Ort DR, and DeLuCIA EH. 2010. Biotic stress globally downregulates photosynthesis genes. Plant, Cell and Environment 33: 1597-1613.

Blamowski ZK, MichąeK W, and Rukasz I. 2003. Effect of mechanical stress on gas exchange and growth of radish and rapeseed plants. Acta Scientiarum Polonorum-Hortorum Cultus 2: 3-11. [In Polish].

EvANS AS. 1991. Whole-plant responses of Brassica campestris (Cruciferae) to altered sink source relations. American Journal of Botany 78: 394-400.

FARQUHAR GD, and SHARKEY TD. 1982. Stomatal conductance and photosynthesis. Annual Review of Plant Physiology 33: 317-345.

Golan K, Rubinowska K, Kmieć K, Kot I, Górska-Drabik E, ŁaGowska B, and MichaŁeK W. 2015. Impact of scale insect infestation on the content of photosynthetic pigments and chlorophyll fluorescence in two host plant species. Arthropod-Plant Interactions 9 (1): 55-65.

Gomez KS, OOSTERHUIS DM, RAJGURU SN, and JOHNSON DR. 2004. Molecular biology and physiology. Foliar antioxidant enzyme responses in cotton after aphid herbivory. Journal of Cotton Sciences 8: 99-104.

Guo DP, Guo YP, ZhaO JP, Liu H, PEng Y, Wang QM, Chen JS, and RAO GZ. 2005. Photosynthetic rate and chlorophyll fluorescence in leaves of stem mustard (Brassica juncea var. tsatsai) after turnip mosaic virus infection. Plant Science 168: 57-63.

Haelterman R, Degroote J, Van Heule D, and Vierendeels J. 2009. The quasi-Newton Least Squares method: a new and fast secant method analyzed for linear systems. SIAM Journal on Numerical Analysis 47: 2347-2368.

Hanson DT, Green LE, and Pockman WT. 2013. Spatio-temporal decoupling of stomatal and mesophyll conductance induced by vein cutting in leaves of Helianthus annuus. Frontiers in Plant Science 4: 1-9.

Hawkins CDB, Aston MJ, and Whitcross MI. 1987. Short-term effects of aphid feeding on photosynthetic $\mathrm{CO}_{2}$ exchange and dark respiration in legume leaves. Physiologia Plantarum 71: 379-389.

Herde O, Peña-Cortés H, Fuss H, Willmitzer L, and Fisahn J. 1999. Effects of mechanical wounding, current application and heat treatment on chlorophyll fluorescence and pigment composition in tomato plants. Physiologia Plantarum 105: 179-184. 
Hinckley TM, and BRAATNE JH. 1994. Stomata. In: Wilkinson RE (ed.), Plant - Environment Interactions, 323-355. Marcel Dekker INC., New York.

HLAVÁČKová V, ŠPundovÁ M, Januš J, NAVRátil M, KouŘil R, and KAŇA R. 2002. Mechanical wounding caused by inoculation influences the photosynthetic response of Nicotiana benthamiana plants to plum pox potyvirus. Photosynthetica 40: 269-277.

Holman EM, and Oosterhuis D. 1999. Cotton photosynthesis and carbon partitioning in response to floral bud loss due to insect damage. Crop Science 39: 1347-1351.

KozioŁek CH, Grams TEE, Schreiber U, Matyssek R, and Fromm J. 2013. Transient knockout of photosynthesis mediated by electrical signals. New Phytologist 161: 715-722.

Messinger SM, Buckley TN, and Mott KA. 2006. Evidence for involvement of photosynthetic processes in the stomatal response to $\mathrm{CO}_{2}$. Plant Physiology 140: 771-778.

Mott KA, and PARKHURST DF. 1991. Stomatal responses to humidity in air and helox. Plant, Cell and Environment 14 509-515.

Muro J, Irigoyen I, and LAmsfus C. 1998. Effect of defoliation on onion crop yield. Scientia Horticulturae 77: 1-10.

Nabity PD, Zavala JA, and DeLucia EH. 2013. Herbivore induction of jasmonic acid and chemical defenses reduce photosynthesis in Nicotiana attenuate. Journal of Experimental Botany 64: 685-694.
Nardini A, Salleo S, and Raimondo F. 2003. Changes in leaf hydraulic conductance correlate with leaf vein embolism in Cercis siliquastrum L. Trees 17: 529-534.

PAUL MJ, and Foyer CH. 2001. Sink regulation of photosynthesis. Journal of Experimental Botany 52: 1383-1400.

PINTO MC. 1980. Regulation of photosynthesis by demand of assimilates: mechanisms possible. Photosynthetica 14: 611-637.

RoITsch T. 1999. Source-sink regulation by sugar and stress. Current Opinion in Plant Biology 2: 198-206.

ShimaZAKI KI, Doi M, Assmann SM, and Kinoshita T. 2007. Light regulation of stomatal movement. Annual Review of Plant Biology 58: 219-247.

SPERRY JS, and POCKMAN WT. 1993. Limitation of transpiration by hydraulic conductance and xylem cavitation in Betula occidentalis. Plant, Cell and Environment 16: 279-287.

STARCK Z, and UbYsZ I. 1976. Source-sink relationships in radish plant. Acta Societatis Botanicorum Poloniae 45: 447-493.

TARTACHNYK I, and Blanke MM. 2002. Effect of mechanicallysimulated hail on photosynthesis, dark respiration and transpiration of apple leaves. Environmental and Experimental Botany 48: 169-175.

Wang Z, Fu J, He M, Tian Q, and CaO H. 1997. Effects of source/sink manipulation on net photosynthetic rate and photosynthate partitioning during grain filling in winter wheat. Biologia Plantarum 39: 379-385. 